\title{
Klart hode,
}

\section{bankende}

hjerte

\author{
«Impossible is nothing,» har Wasim Zahid ført opp som motto på sin Twitter-profil. Intet \\ mindre! Målt etter evner og engasjement ser det ut til at han hittil har levd som han lærer. \\ Men hva er det som driver ham? Og blir han aldri sliten?
}

- Av og til, når jeg skal kjenne etter lymfeknutene på halsen, tar jeg ansiktet til pasienten i hendene mine. Jeg vet ikke hvorfor jeg gjør det, sier han ettertenksomt mens han fester blikket et sted i skogen bak Rikshospitalet. - Det er jo egentlig en kraftfull ting å gjøre, og særlig de gamle setter pris på nærheten det gir. Det hender at de griper hånden min, og vi kan få sterk emosjonell kontakt.

Generelt bruker jeg mye berøring i konsultasjonen, der det føles naturlig. Ikke-verbal kommunikasjon betyr mye for tilliten. Jeg tror det kan medvirke til at pasienten kommer seg fortere.

Ved siden av et utrettelig engasjement på Twitter er Wasim Zahid til daglig ph.d.-stipendiat ved Hjerteavdelingen ved Oslo universitetssykehus, Rikshospitalet. Vi har avtalt å treffes der. Personalkantinen er passe sommerstille, så vi slår oss ned der. De to eldste guttene hans sitter på bordet ved siden av. Tålmodig spiser de brødskiver med Nugatti. I tillegg til en ph.d.-grad har den norsk-pakistanske legen et mål om å bli spesialist i kardiologi - for det er klinikken som ligger hans hjerte nærmest. Akkurat nå er det imidlertid fordypning i hjertemuskelfysiologi som gjelder.

\section{Guds domene}

Selv om intervjuobjektet $\mathrm{i}$ den senere tid er blitt kjent som selveste «Twitter-legen» og stadig stikker hodet frem i mediene og mener noe om likt og ulikt, er han rask med å poengtere at det er legeyrket han identifiserer seg sterkest med.

- Jeg er en lege med sterk forankring i den norske legetradisjonen, understreker han, - og jeg ønsker å være en pasientvennlig lege. Jeg forsøker å skape en følelse hos pasienten av at han blir tatt på alvor, og vil at han skal oppleve å komme til en lege som utstråler faglig trygghet. Det krever at jeg er empatisk og lyttende. Pasienten skal føle seg ivaretatt og ha en forvissning om at nødvendig utredning og diagnostikk blir gjort. Det handler i bunn og grunn om kommunikasjon.

Tilfeldig var det neppe at en mann med Zahids bakgrunn endte opp som lege. Blant norsk-pakistanere generelt står legeyrket høyt i kurs. I en rekke land i Østen har legen en spesiell status.

- I mange asiatiske kulturer går helse, liv og død sammen med det guddommelige, forteller 37-åringen. - En som har kunnskap om kroppen og som opererer i grenselandet

\section{«Jeg føler at når jeg eksponerer meg, både i mediene og på jobben, representerer jeg ikke bare meg selv, men hele mitt folk»}

mellom liv og død, blir høyt aktet, for da er man en del av Guds domene. Jeg tror ikke at alle norsk-pakistanere som søker seg til legeyrket i dag, tenker bevisst på dette, men det er vel noe som ligger der i underbevisstheten.

En annen faktor er forventningene som lå i familien. For Wasims del var det et klart ønske fra foreldrene om at barna skulle utdanne seg innenfor helsevesenet. Han avviser likevel at han har opplevd det som et press.

- Ønsket skapte en interesse i meg som gjorde at jeg fra tidlig barndom ville bli lege. Og da jeg søkte på medisinstudiet, var det fordi jeg selv ville det, det var ikke på grunn av mine foreldre, understreker han.

\section{Klassereisen}

Wasim Zahids foreldre innvandret til Norge i begynnelsen av 1970-årene. Han ble født her i landet og vokste opp på Hovseter i Oslo. Tidligere i år ble Zahid intervjuet i programmet Migrapolis i NRK, der han snakket om det å være klassereisende. Med minoritetsbakgrunn og en far som jobbet i Oslo Sporveier var det lett å føle seg annerledes under oppveksten på Oslo vest. Faren kom fra en bondefamilie i Pakistan. Hans egne foreldre var analfabeter. Likevel så de verdien av utdanning. Dette ble plantet i ham. Han reiste til storbyen Peshawar og utdannet seg til advokat. Da han kom til Norge, måtte han starte på bunnen igjen.

- Hele sitt arbeidsliv har pappa vært arbeider, det meste av tiden som T-banefører og etter hvert billettkontrollør i Oslo Sporveier. Det var nok sårt for ham. Men han gjorde det fordi han ville gi barna sine en bedre fremtid.

Når det gjelder klassereisen, så er jeg nok en del av et kontinuum, sier Wasim ettertenksomt. - Foreldrene mine hadde utdanning, så akademisk har ikke reisen vært lang. Den største klassereisen er økonomisk og sosialt, ettersom vi i voksen alder fikk høyere utdanning og gode yrker. Utdanningen har vært vår vei opp og frem. - Mange klassereisende kan føle at de ikke hører hjemme noe sted. Er det en følelse du kjenner deg igjen i?

- Artig at du spør om det, for akkurat det har jeg tenkt mye på, sier han ivrig. - Jeg tror at mellomgenerasjonen, som jeg tilhører, er rotløs. Vi har tilknytning både til våre foreldres hjemland og til Norge. Foreldrene mine føler seg fremdeles pakistanske og drømmer stadig om å reise tilbake, selv om det er 40 år siden de reiste derfra. Selv har jeg ingen sterk nasjonalfølelse for noen av landene. Men jeg ser for meg - og håper - at når barna mine blir voksne og får egne barn, er begrepet «nordmann» ikke eksklusivt knyttet til en lys, blek eller blond person. Er man født og oppvokst her, har man tilhørighet herja, så er man nordmann. 


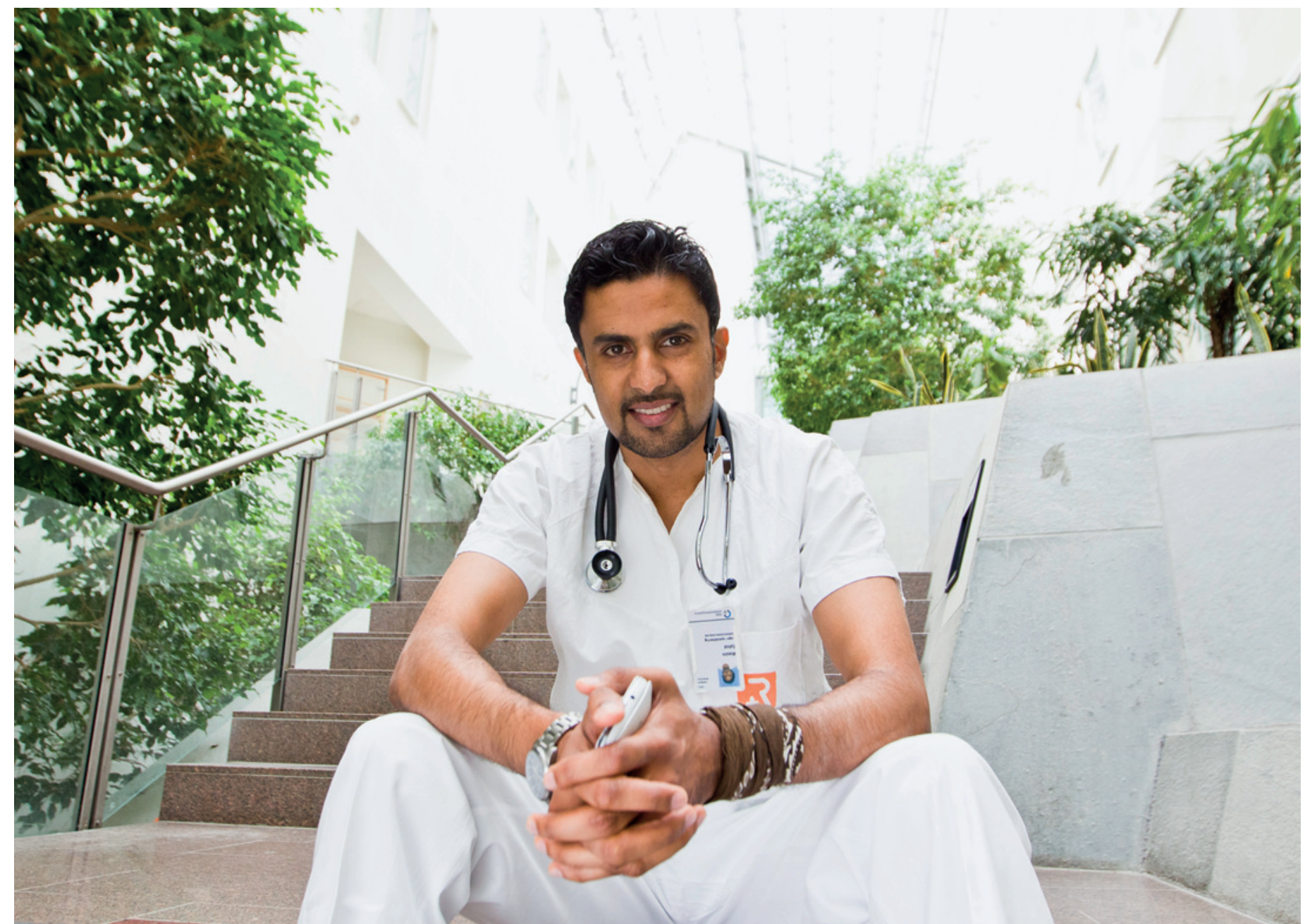

Foto Vegard Grøtt/NTB scanpix

\section{Wasim Zahid}

Født 1975 i Oslo

- Artium Persbråten videregående skole 1994

- Cand.med. Universitetet i Oslo 2003

- Ph.d.-kandidat Det medisinske fakultet, Universitetet i Oslo, fra 2010

- Lege i spesialisering ved Kardiologisk avdeling, Oslo universitetssykehus, Rikshospitalet, fra 2010

- Lege i spesialisering ved Medisinsk avdeling, Drammen sykehus, 2005-10

- Styremedlem i Minotenk (minoritetspolitisk tenketank) fra 2010

- «Twitterlegen»
Jeg synes for øvrig at Norge er et fantastisk land! legger han til. - Det må være med! Det norske velferdssystemet! Fordelingen av godene, skattesystemet der alle bidrar, slik at vi får veier, helse og skoler. De små tingene, som at treåringen automatisk blir innkalt til tannlegekontroll.Noen har faktisk sittet og tenkt at det er fornuftig å kalle inn barn til kontroll. Man har laget systemer for at alle skal bli fanget opp. Det samme gjelder vaksinasjoner og svangerskapskontroller.

Man tar det som en selvfølge, men det er store systemer som krever enorm logistikk. Jeg kan ikke se for meg at man kan få til noe liknende de neste 100 år i mine foreldres hjemland.

\section{Idealinnvandreren?}

«Det er ikke tilfeldig at han ble lege, kjører Landcruiser og har bosatt seg i Lommedalen,» sier en venn. Etter et kjapt søk på Google finner jeg bilder av en vakker kone, fire flotte barn og en smilende mann som triller barnevogn. Han fremstår som moderne, liberal, integrert - selve idealinnvandreren. Hva ligger bak veivalgene underveis, undrer jeg. Og har det hatt en pris?

Han drar på det og virker brått noe ukomfortabel.

- Jeg har aldri tenkt bevisst at jeg skal jobbe meg oppover, sier han nølende. - Jeg tror det har fulgt en naturlig utvikling uten å være et mål. Men jeg ser og får høre, også innad i innvandrermiljøet, at den reisen jeg har gjort, er det mange som ser på som et ideal.

Zahid blir nettopp fremhevet som et forbilde av folk som kjenner ham. Og det å være et forbilde tar han også som et ansvar.

- Forbilder er viktige, særlig i vårt miljø, for det er få av dem. Dermed følger det med et spesielt ansvar, bekrefter han. - Jeg føler at når jeg eksponerer meg, både i mediene og på jobben, representerer jeg ikke bare meg selv, men hele mitt folk. Jeg må prestere hundre og ti prosent hele tiden, for jeg vet at jeg blir bedømt strengere. Det føler jeg i alle fall. Kanskje er jeg unødvendig paranoid? legger han undrende til. 
Venner og familie bekrefter at han stiller høye krav til seg selv. Det blir aldri bra nok. Han er alltid på vei. Og det kan være slitsomt. - Kan det være en belastning alltid å være representant for en minoritet?

- Ja, jeg tenker i alle fall mye på det. Jeg føler at jeg må gjøre det bra, for hvis jeg skuffer, hvis jeg gjør det dårlig, så har folk lettere for å tenke «utenlandske leger...».

\section{Synliggjøring}

Mye av hans engasjement offentlig i den senere tid har nettopp sammenheng med at han ønsker å bidra til å synliggjøre etniske minoriteter i det norske samfunnet. Og det gleder ham veldig at flere og flere norsk-pakistanere profilerer seg i ulike sammenhenger.

- For eksempel å se en økonomiekspert med norsk-pakistansk bakgrunn som snakker om norsk økonomi, det er uvurderlig, sier han engasjert. - Eller en TV-lege med et fremmed navn og mørk hud som snakker generelt om helse for nordmenn. Dette er med på å avmystifisere den brune mannen. Den effekten det har på folk å se minoriteter i vanlige situasjoner, gjør noe med holdningene.

- Du har selv fått mye oppmerksomhet, og du stiller opp. Hvordan har det vært?

- Jeg tror mediene er interessert i nye ansikter og noen som kan presentere noe nytt. Og hvis du er villig til å legge deg selv ut, er det mange muligheter. Med minoritetsbakgrunn har man noe ekstra å spille på. - Du blir ikke sliten?

- Jo, jeg tror at jeg blir det. Jeg må passe på ikke å bli utbrent. Akkurat nå står jeg på hundre og tjue prosent. Det kan bli litt mye.

\section{\#Mediquiz}

Zahid er spesielt blitt kjent for sine såkalte mediquiz - en slags medisinsk gjettelek på nettforumet Twitter. Han forteller at det hele startet da han jobbet som assistentlege ved Drammen sykehus. På morgenmøtene hendte det ofte at han laget en quiz dersom han hadde hatt et spennende tilfelle på vakt. Mange av kollegene syntes dette var morsomt, og han fikk etter hvert ideen om å legge noe tilsvarende ut på nettet. Så tok det av!

- Folk var veldig interessert, og dette inspirerte meg til å utbrodere det i større grad, som i TV-serien House, med karakterer, konflikter og intriger, ler han. - Jeg pleier å ta utgangspunkt i en sykdom og en sykehistorie. Det starter med at pasienten går til legen sin, blir sykere, så innlagt i sykehus. Jeg finner så på komplikasjoner og annet som kan skje pasienten og legger ut meldinger med brokker av informasjon, litt mer for hver melding.

For meg handler dette også om helseinformasjon. Legeyrket har vært noe som vi leger har holdt på med for oss selv. Det er fremdeles lukket og hemmelighetsfullt. Folk er nysgjerrige på hva leger egentlig gjør. Jeg ser ingen grunn til å holde dette skjult. Det åpner opp et lite vindu til hverdagen vår, til den diagnostiske tankegangen. Det er folk fascinert av.

Zahid ser på sosiale medier som en ny arena for helseopplysningsarbeid. Han mener det er et stort behov for det. Helse er noe som angår alle, og folk synes det er spennende å komme i direkte kontakt med en fagperson på nettet.

Styrken og dynamikken som ligger i sosiale medier som Twitter, illustreres godt av følgende historie, der Wasim Zahid tok opp forskrivning av p-piller til unge jenter.

- Jeg var på jobb og hadde lite å gjøre, forteller han ivrig. - Jeg valgte med vilje en 12 år gammel jente som ville ha p-piller og spurte om kolleger ville forskrevet uten å kontakte foreldrene? Det eksploderte på Twitter. Og

\section{«Med minoritetsbak- grunn har man noe
ekstra å spille på»}

journalister fanget det opp. VG laget et førstesideoppslag, samme kveld kom det på Aktuelt på NRK, helseministeren uttalte seg. Og jeg var veldig stolt over at jeg hadde startet dette. Dette viser kraften i de nye mediene.

\section{God helse for alle}

Helseinformasjon er noe intervjuobjektet brenner for $-\mathrm{i}$ bred forstand. Han er spesielt opptatt av helse hos minoritetsbefolkningen i Norge, siden han selv tilhører den.

- Minoriteter i Norge har generelt dårligere helse enn etniske nordmenn. Dette henger sammen med både sosial klasse og genetiske anlegg og det at innvandrere har kropper som er tilpasset det å drive jordbruk, med lavt kaloriinntak og mye kroppsarbeid. Så har de kommet til Norge, fått økt velstand, har økt kaloriinntaket og er blitt mindre fysisk aktive. Mange av dem som er syke, tilhører min foreldregenerasjon. Det tradisjonelle helseopplysningsprogrammet som er rettet mot etniske nordmenn, er ikke så effektivt overfor dem. Dette med å gå tur i skogen, for eksempel, det er helt ukjent. Hvorfor skal man gjøre det? Mange er utslitt etter å ha arbeidet i tunge yrker i 40 år. De forbinder ikke trim med velbehag, men med slit. - Hvordan kan man nå frem til disse gruppene?

- Jeg har tro på dette med forståelse. Alle ønsker seg god helse og et langt liv. Hvis man på en enkel måte kan få folk til å forstå mekanismene bak utvikling av sykdom og så setter i gang tiltak for å bedre helsen, tror jeg man kan få folk til å endre atferd. Jeg tror det vil kreve helseopplysningsarbeid i lokalmiljøene, for eksempel i de deler av Oslo med høy innvandrertetthet. Det handler om å nå folk der de er.

\section{«Hvis jeg ikke levde mitt eget liv ville jeg levd hans»}

Følger man Wasim Zahid på Twitter, opplever man en mann med et enormt engasjement i en rekke saker - alt fra avanserte medisinske spørsmål og aktuelle nyhetssaker til mer trivielle saker som sport og fritidssysler blir behørig kommentert og diskutert. Mye av hans tid går til Twitter og bruk av medier generelt. Hva sier familien til dette?

- Jeg har et bredt samfunnsengasjement og prøver å følge med på mye, og det plinger i lommen hver gang det kommer en melding. Men barna blir veldig forvirret dersom all oppmerksomhet gis til mobiltelefonen. Jeg prøver å ha et bevisst forhold til dette, men må stadig minnes på det. Han er i alle fall veldig til stede under vår samtale. Det slår meg at han i alt han sier og gjør fremstår som enormt gjennomtenkt og velformulert. Er det ingen riper i lakken, undrer jeg?

Han virker umiddelbart litt forvirret og flakker med blikket før han svarer: - Er jeg for seriøs? Jeg vet ikke helt det. Jeg har normale «guttete» interesser. Liker raske biler, sport, musikk, har et fett hjemmekinoanlegg (som han for øvrig stolt tok bilder av og sendte til magasinet Lyd \& bilde, der de kom på trykk). Det er viktig for meg å gjøre morsomme ting i livet. Jeg har en filosofi om at livet vi har her, er det vi har, og at vi må gjøre det beste ut av det, utnytte tiden, skape gode minner.

Jeg vet ikke helt om dette kvalifiserer for riper. Kanskje er det riktig som hans profilerte advokatvenn, Venstre-politikeren Abid Raja, sier: «Han er flink i alt han gjør, han er en dedikert far og ektemann - likevel er han en jordnær type. Han er idealmannen. Hvis jeg ikke levde mitt eget liv, ville jeg levd hans.»

\section{«Jeg holder ditt hode»}

Stein Mehren har skrevet et av de fineste kjærlighetsdiktene jeg kjenner. «Jeg holder ditt hode / i mine hender, som du holder / mitt hjerte i din ømhet / slik allting holder og blir / holdt av noe annet enn seg selv») lyder de første verselinjene. Jeg ser for meg Wasim Zahid som holder pasientens ansikt i sine hender. Det virker som han har både hodet og hjertet på rett sted, denne mannen. Trygghet og tillit er to av hjørnestenene i lege-pasient-relasjonen, og jeg tror han har rett når han sier at den samhørigheten han noen ganger klarer å få til i konsultasjonen, er med på å styrke effekten av behandlingen og av prognosen til pasienten.

\section{Lisbeth Homlong}

lisbeth.homlong@hotmail.com Institutt for helse og samfunn Universitetet i Oslo 